\title{
Advanced dementia in a sample of Brazilian elderly: Sociodemographic and morbidity analysis
}

\author{
Marco Túlio Gualberto Cintra ${ }^{*}$, Nilton Alves de Rezende ${ }^{2}$, Henrique Oswaldo da Gama Torres ${ }^{3}$ \\ ${ }_{1}^{1}$ PhD Student in Adult Health at Universidade Federal de Minas Gerais (UFMG). Geriatric Physician, Hospital das Clínicas da UFMG, Belo Horizonte, MG, Brazil \\ 2Postdoctor in Medical Epidemiology from UFMG. Full Professor, Department of Internal Medicine, Faculdade de Medicina da UFMG (FM-UFMG), Belo Horizonte, MG, Brazil \\ ${ }^{3} \mathrm{PhD}$ in Adult Health from UFMG. Adjunct Professor, Department of Internal Medicine, FM-UFMG, Belo Horizonte, MG, Brazil
}

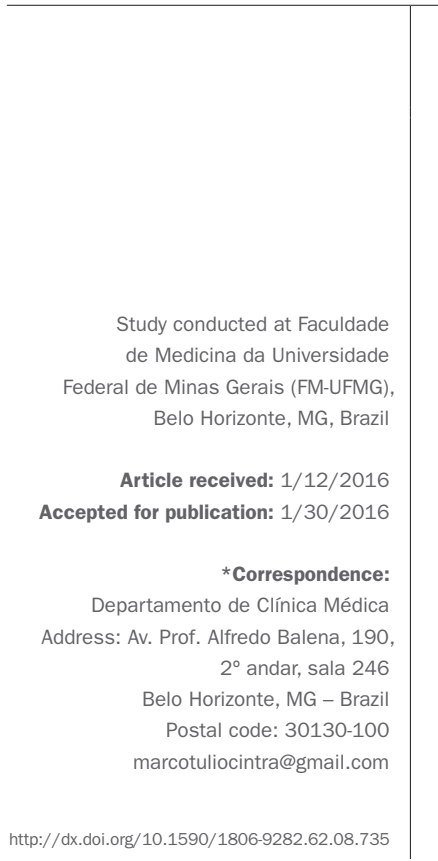

\section{SUMMARY}

Introduction: To investigate the sociodemographic and morbidity profile of advanced dementia patients and sociodemographic data of their primary caregivers. Method: Data was obtained from 67 elderly recruited for an observational prospective study, through interviews performed with primary caregivers. For statistical analysis, the Statistical Package for the Social Sciences (SPSS ${ }^{\circledR}$ ) for Windows ${ }^{\circledR}$, version 19.0. was employed.

Results: Advanced dementia patients were mostly women, widows, and non-institutionalized, with low-income. An elevated rate of stroke, sarcopenia, and pressure ulcers in this population is noted. Caregivers were mostly women, married, children of the studied patients, and unemployed. Only one third of caregivers were hired for the task.

Conclusion: Patients with advanced dementia present a high morbidity profile, low income, and depend on the care given by family members, mostly unemployed daughters.

Keywords: Alzheimer's disease, comorbidity, socioeconomic factors, aged.

\section{INTRODUCTION}

Demographic transition, characterized by rapid decline in fertility and population growth, leads to a reduction in the proportion of the young population and an increase in the elderly population, aged 60 years or older..$^{1,2}$ The result of this fact is an increased number of cases of chronic degenerative diseases, including dementia. ${ }^{3}$ The prevalence of dementia in Brazil is estimated at $7.1 \%$ among the elderly. ${ }^{4}$ According to the population census, in 2010 there were 20,590,599 inhabitants aged 60 years or older in Brazil (10.79\% of the population). Considering the prevalence of dementia, it is estimated that approximately $1,500,000$ elderly individuals present this disease. ${ }^{5}$

Advanced stage dementia is characterized by significant cognitive and functional decline. There is a noted dependency for self-care, with the need for assistance in simple tasks such as transfers, bathing, and dressing. This is classified by the Clinical Dementia Rating (CDR) as stage 3, by the Global Deterioration Scale (GDS) as a score $\geq 6$, by the Functional Assessment Staging Tool (FAST) as a score $\geq 6$ and by the Mini Mental State Examination (MMSE) as a score of less than ten points. We can also observe worsening of associated psychological and behavioral symptoms, a higher level of burden on the caregiver, and a greater risk of institutionalization. ${ }^{6}$

It should be noted that among patients with advanced dementia there is a subgroup at a very advanced stage, estimated at $17 \%$ of elderly people with dementia aged over 75 years, in which there is a MEEM of less than two points and maximum reliance on self-care. ${ }^{6}$ This is characterized by progressive loss of the ability to walk, causing immobility syndrome, which is defined by the presence of multiple contractures and cognitive decline associated with two of the following conditions: aphasia, dysphagia, pressure ulcers, and the presence of urinary and/or fecal incontinence. ${ }^{7}$ The presence of eating disturbances such as refusal to eat and oropharyngeal dysphagia is common, raising the risk of aspiration pneumonia.

The subpopulation of patients with advanced dementia in Brazil has not been properly characterized and estimated. The clinical and sociodemographic context of these patients is unknown, as well as the sociodemo- 
graphic profile of caregivers. Therefore, the objective of this study was to assess the sociodemographic and clinical context of elderly people with advanced stage dementia, as well as the sociodemographic data of the primary caregivers of such patients.

\section{Method}

The data was obtained from elderly people recruited for an unblinded, non-randomized, prospective observational study that evaluated mortality, the incidence of aspiration pneumonia, and hospitalization of patients in advanced stages of dementia. ${ }^{8}$

The sample consisted of elderly patients with probable or possible Alzheimer's dementia in advanced stage and dysphagia. Half of these patients were using alternative feeding routes (nasoenteral catheter or gastrostomy). The other half was fed exclusively by mouth. The elderly individuals included in the study were recruited at the geriatrics clinic of the Universidade Federal de Minas Gerais (UFMG), at the emergency room of the UFMG's Hospital das Clínicas, at the Center-South Emergency Unit (UPA-Center-South), at the wards of Hospital Risoleta Tolentino Neves, and at the patient's home. All of the above-mentioned health units are public and administered by the UFMG. The study was approved by the UFMG Research Ethics Committee under number 0164.0.203.000-11.

We included patients aged over 60 years with probable or possible Alzheimer's dementia (AD) according to the criteria established by Mckhann et al. (2011) classified on the Functional Assessment Staging Tool (FAST) scale as 7A to 7F (Sclan and Reisberg, 1992), with complete dependence for Basic Activities of Daily Living (ADLs) as classified using the Katz Index (Lino et al., 2008), with the presence of moderate to severe oropharyngeal dysphagia confirmed by clinical assessment, according to the protocol given by Padovani et al. (2007). ${ }^{9-12}$

Elderly people with neurological dysphagia after a cerebrovascular accident (CVA), secondary to amyotrophic lateral sclerosis or Parkinson's diseases were excluded. Tracheostomy patients or those with the presence of any type of neoplasm, except for those in complete remission, were also excluded. Dysphagic subjects with a history of CVA, in which the onset of dysphagia presented no temporal association with this neurological event, were not excluded.

The calculation of the sample has been previously published. ${ }^{8}$ The demographic and clinical data was obtained through interviews held with the primary caregivers. Where possible, the information was supplemented by data from medical records, hospital discharge sum- maries and supplementary examinations. Primary caregiver is defined as the person with main, full or greatest responsibility for the care provided to the patient at home. ${ }^{13}$ All of the caregivers were interviewed exclusively by one of the researchers (MTGC). The burden on the caregiver was analyzed using the Zarit scale. ${ }^{14}$

The nutritional status was assessed by measuring the left calf circumference (CC), in which values of less than $31 \mathrm{~cm}$ indicate sarcopenia and a worse nutritional status. ${ }^{15,16}$ Pressure ulcers were evaluated and classified, and sorted according to the National Pressure Ulcer Advisory Panel's, revised version $2007 .{ }^{17}$ Serum albumin levels were noted when available.

Analysis of the continuous variables was performed by calculating the mean, median, and standard deviation and comparing them using the appropriate tests for the type of distribution. The categorical variables were compared using chi-squared test or Fisher's exact test. Normality assessment of the continuous variables was carried out using Shapiro-Wilk test, and the comparison of averages using Student's t-test (for normal distribution) or MannWhitney U test (for non-normal distribution). For the statistical analysis, we used the Statistical Package for the Social Sciences $\left(\right.$ SPSS $^{\circledR}$ ) for Windows ${ }^{\circledR}$, version 19.0 .

\section{RESULTS}

Sixty-seven (67) dysphagic elderly people in advanced stages of dementia were recruited, 36 in use of the oral route, 28 using a nasogastric catheter and three submitted to gastrostomy. Most patients were recruited during hospitalization (58.2\%). The average age was $84.79 \pm 7.02$ years, $85.1 \%$ were female, with formal education for $2.90 \pm 3.73$ years and income of $1.23 \pm 0.90$ minimum wages. Fifty-seven percent (57\%) of patients were widows, $25.4 \%$ were married, and $14.9 \%$ were single. The rate of institutionalized individuals was $9 \%$.

In relation to the etiological diagnosis of dementia, $55.2 \%$ had probable $\mathrm{AD}$ and the remainder, possible $\mathrm{AD}$. In relation to the assessment of severity, $14.9 \%$ presented FAST 7A or 7B, while $85.1 \%$ of the elderly people were in FAST phase 7C or worse, with a predominance of FAST 7D (38.8\%). On average, the subjects had been diagnosed with dementia for $5.80 \pm 3.57$ years with onset of dysphagia $12.60 \pm 15.04$ months before our investigation. The subjects in the group using an alternative feeding route were recruited $51.28 \pm 96.94$ days (median of 11.5 days) after introducing the feeding device.

The patients resided in households inhabited by $3.79 \pm 1.60$ people, with $1.64 \pm 0.71$ elderly individuals and $2.43 \pm 1.25$ residents contributing to the family income. 
Only $6 \%$ of the patients did not present any source of income, while the majority of seniors received a retirement pension (50.7\%). Figure 1 characterizes the subjects with dementia according to the type of income. The income of these families totaled $4.39 \pm 7.50$ minimum wages; therefore, the salaries received by the elderly corresponded to $28.2 \%$ of the average household income.

On average, $3.78 \pm 1.56$ comorbidities were reported, with the most frequent being CVA in $41.8 \%$, systemic arterial hypertension (SAH) in $65.7 \%$, and diabetes mellitus (DM) in $20.9 \%$. There was no statistical difference between the groups with or without an alternative feeding route in relation to the number of pathologies $(\mathrm{p}=0.306)$ and the diagnosis of these comorbidities: CVA ( $\mathrm{p}=0.331)$, SAH $(\mathrm{p}=0.397)$ and $\mathrm{DM}(\mathrm{p}=0.753)$.

The patients received an average of $3.24 \pm 1.97$ medications, with $25.4 \%$ using five or more, which is known as "polypharmacy."18 There were no differences between the groups with or without an alternative feeding route in relation to the amount of medication prescribed $(\mathrm{p}=0.057)$. The classes of medications prescribed the most were antihypertensive drugs (53.2\%), antipsychotics (33.9\%), antiplatelet agents (29\%), benzodiazepines (27.4\%), and antidepressants (19.4\%). Opioids, dipyrone or acetaminophen were prescribed for analgesia in only four patients, while five subjects $(7.5 \%)$ were using acetylcholinesterase inhibitors in the very advanced stage of dementia.
We found that $65.7 \%$ of the subjects had pressure ulcers, with an average of 1.97 ulcers. The patients with an alternative feeding route had the highest number of pressure ulcers ( 2.74 ulcers $v s .1 .31, \mathrm{p}=0.035$ ). In relation to the severity of the pressure ulcers, stage 2 was the most common (present in $65.9 \%$ of patients), followed by grade 1 (45.5\%), grade $3(15.9 \%)$, grade $4(13.6 \%)$ and deep tissue injury (13.4\%). There was a tendency towards greater severity of ulcers in the group with alternative feeding routes, with $25.8 \%$ grade 3 and 4 lesions versus $8.3 \%$ in the elderly people on the oral route $(\mathrm{p}=0.054)$.

The average $C C$ value was $26.03 \pm 3.72 \mathrm{~cm}(p=0.750$ between the oral and alternative feeding groups). Only $13.4 \%$ of the elderly people presented calf values greater than or equal to $31 \mathrm{~cm}$. Only 19 patients had serum albumin results, with average values of $2.88 \pm 0.86 \mathrm{mg} / \mathrm{dL}$ ( $\mathrm{p}=0.996$ between the oral and alternative feeding groups).

The patients that were institutionalized were excluded from the assessment of the primary caregivers. The caregivers were mostly female (87.1\%) and had an average age of $53.23 \pm 11.46$ years, with $23.9 \%$ older than 60 years and average education of $7.80 \pm 4.11$ years. Most were married (57.6\%), followed by single (16.9\%), divorced (13.6\%), and widowed (10.2\%) caregivers. They were, for the most part, the children of the patients (67.2\%), followed by grandchildren and spouses $(8.2 \%$ in each subgroup). Other relatives totaled to $14.8 \%$. Only $1.6 \%$ of primary caregivers were hired without family connections.

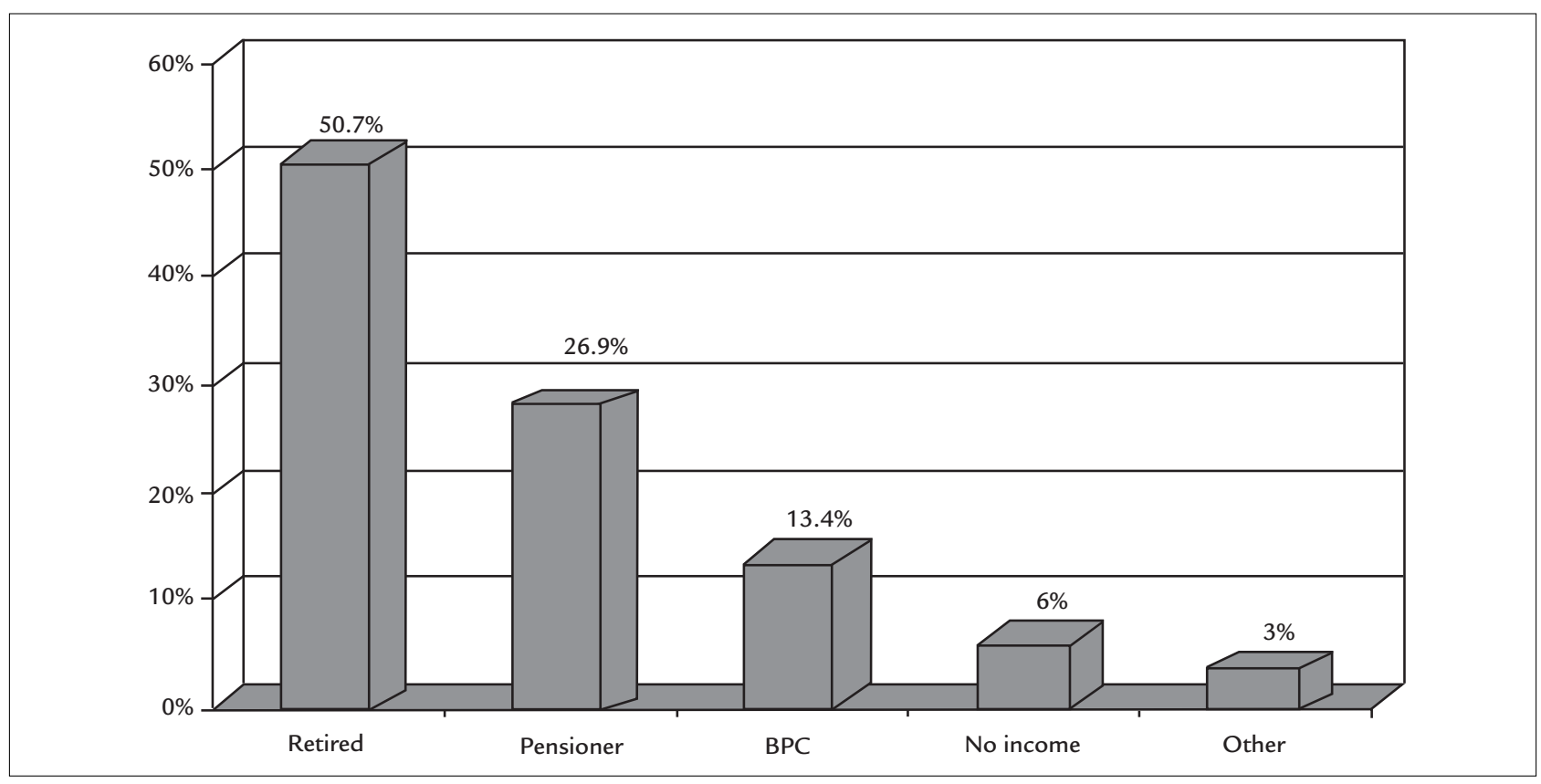

FIGURE 1 Classification of income type.

BPC: Brazilian antipoverty welfare program 
The caregivers were mostly unemployed (45.9\%), followed by retirees $(27.9 \%)$, as well as $24.6 \%$ who were working at the time of recruitment. One third of the elderly people were assisted by hired caregivers, who received an average of $1.04 \pm 0.59$ minimum wages. However, the hired professional was the primary caregiver in only one home. There was no difference between the oral and alternative feedings groups in relation to the sociodemographic variables examined (Table 1).

When caregiver burden was assessed, significant burden values were noted in both, those responsible for the care of elderly individuals with exclusive oral feeding (30.0) as well as those responsible for the care of dementia patients with alternative feeding routes (27.04), with no statistical difference between the groups $(\mathrm{p}=0.398)$. No influence was observed regarding prevalence $(\mathrm{p}=0.344)$ and number of pressure ulcers $(\mathrm{p}=0.355)$, calf circumference $(\mathrm{p}=0.162)$ and the primary caregiver burden $(\mathrm{p}=0.870)$ when hiring caregivers.

\section{Discussion}

The subjects of this study included elderly people with advanced age, who were predominantly female, with low education and widowed, in accordance with that described in the literature. ${ }^{19}$ However, we must highlight the low rate of institutionalization when compared to other studies, which present a rate of over $50 \% .{ }^{20-27}$ The exception to this is a study by Jaul et al. (2006) which detected that $24 \%$ of elderly people with exclusive oral feeding and $45 \%$ with alternative feedings routes were institutionalized..$^{28}$ All of these studies were performed in other countries, such as the United States, which have economic, social, and cultural differences that could justify the discrepancy.

The low rate of institutionalization may be due to an insufficient number of places at charitable or public longstay institutions for the elderly (ILPI), in addition to low family income to cover the cost of private ILPIs. This reality has been shown by Chaimowicz and Greco (1999), who demonstrated that $0.9 \%$ of women and $0.3 \%$ of men over 60 years of age in Belo Horizonte were institutionalized, and that ILPIs presented an occupancy rate of $92 \%{ }^{29}$ Nevertheless, the results cannot be generalized to the entire Brazilian population because only subjects served by the public health system were included.

Data from the National Survey by Household Sampling (PNAD, in the Portuguese acronym) in 2004 shows that in households with per capita income of one minimum wage have an average of four people in the southeast region, similar to the results in this study. ${ }^{30}$ It was found that elderly individuals with dementia contributed to $28.2 \%$ of the family income, in accordance with studies which have shown that the share of pensions and benefits in total household income is increasing progressively in Brazil. ${ }^{31}$

In the assessment of the sociodemographic data of the primary caregivers of elderly people with advanced dementia, it was found that they are mostly female aged 53.2 years on average. They are mostly the children of patients, married, have 7.8 years of formal education, and

TABLE 1 Analysis of sociodemographic data comparing oral and alternative feeding groups.

\begin{tabular}{llll} 
& Oral feeding group & Alternative feeding group & P-value \\
\hline Patient's sex & $77.8 \%$ female & 93.5 female & 0.093 \\
\hline Patient's age & $84.08 \pm 7.11$ years & $85.61 \pm 6.93$ years & 0.378 \\
\hline Patient's educational level & $2.59 \pm 3.17$ years & $3.31 \pm 4.39$ years & 0.873 \\
\hline Patient's income & $1.16 \pm 0.47 \mathrm{MS}$ & $1.31 \pm 1.23 \mathrm{MS}$ & 0.603 \\
\hline Caregiver's sex & $85.3 \%$ female & $89.3 \%$ female & 0.719 \\
\hline Caregiver's age & $53.79 \pm 13.20$ years & $52.52 \pm 9.01$ years & 0.670 \\
\hline Caregiver's educational level & $7.56 \pm 3.89$ years & $8.11 \pm 4.42$ years & 0.878 \\
\hline Number of individuals per household & $3.82 \pm 1.64$ & $3.74 \pm 1.58$ & 0.929 \\
\hline Number of individuals with income per household & $2.38 \pm 0.85$ & $2.50 \pm 1.66$ & 0.957 \\
\hline Number of elderly individuals per household & $1.71 \pm 0.63$ & $1.56 \pm 0.80$ & 0.198 \\
\hline Family income & $3.19 \pm 1.74 \mathrm{MS}$ & $5.73 \pm 10.81 \mathrm{MS}$ & 0.692 \\
\hline$\%$ of elderly individuals with paid caregivers & $26.5 \%$ & $42.3 \%$ & 0.197 \\
\hline Amount paid to caregiver & $0.90 \pm 0.34 \mathrm{MS}$ & $1.21 \pm 0.74 \mathrm{MS}$ & 0.345 \\
\hline Burden on the caregiver - the Zarit scale & 30.0 & 27.04 & 0.398 \\
\hline MS: minimum salary. & & &
\end{tabular}


almost half are unemployed. Requena et al. (2011) conducted a retrospective study with 27 advanced dementia patients in Spain and described that most primary caregivers are women $(81.5 \%)$, have an average age of 63 years, and are the children of the elderly people with dementia (74.1\%). ${ }^{32}$ Figueiredo and Souza (2008) evaluated 52 patients with dementia in Portugal, $61.5 \%$ of whom were completely dependent, and noted that $67.7 \%$ of the caregivers were aged between 41 and 60 years, $88.5 \%$ were female, $51.9 \%$ were the patients' children, $75 \%$ were married, $53.8 \%$ had up to 4 years of education, and only $25 \%$ were employed..$^{33}$ Babarro et al. (2004) conducted an intervention study in Spain with caregivers of elderly people with dementia and reported that most caregivers are women (83.9\%), aged 54.6 years on average, married (82.5\%), with up to 4 years of formal education $(70.2 \%)$ and are usually the children of the patient (58.5\%). ${ }^{34}$ As such, the social and demographic profile of caregivers to the elderly in this study is similar to that observed in other countries.

We can highlight that only a third of patients had hired caregivers, and that these received low pay. The rate is higher than that found by Toribio-Díaz et al. (2013) in a sample of 129 Spanish individuals with moderately advanced Alzheimer's dementia, among whom only $11.6 \%$ had hired caregivers. ${ }^{35}$

It was observed that $41.8 \%$ of the sample presented a CVA episode. A similar rate (46.7\%) was found by Arizon et al. (2008) in elderly people institutionalized in Israel..$^{21}$ Lower prevalence rates have been described in the United States by Peck (1990) and Mitchell (1997), as well as in Spain by Alvarez-Fernández (2005) and in Israeli patients by Jaul (2006), who reported rates between 0 and $34 \% .22,26-28$

The proportion of hypertensive patients was $65.7 \%$, and the proportion of patients with DM was $20.9 \%$. Lima-Costa et al. (2011) demonstrated that SAH is selfreported by $53.3 \%$ of the elderly population in Brazil, and DM by $16.1 \%$, while Pimenta et al. (2013) detected a SAH rate at $74.3 \%$ in subjects over 60 years of age with dementia. ${ }^{35,36}$ Alvarez-Fernández et al. (2005) reported that the proportion of hypertensive elderly individuals among patients with dementia was $22.4 \%$, which is below that found in this study. ${ }^{22}$ In relation to the prevalence of DM, Arizon et al. (2008) recorded a similar prevalence rate to that found in our study $(24.5 \%)$, while Mitchell (1997) and Alvarez-Fernández (2005) reported lower values (11.7 and 6\%, respectively). Meanwhile, Jaul et al. (2006) found a prevalence of $39 \%$ in the group with the alternative feeding route and $60 \%$ in the exclusive oral group, which is higher than that found by us. ${ }^{21,22,26,28}$
According to the aforementioned studies, the rate of hypertensive and diabetic patients is close to that described in the literature. . $^{37,38}$

The presence of four chronic diseases per patient was observed, a high vulnerability clinic profile, which is slightly worse than that verified by Nair et al. (2000), who reported 1.5 disorders per patient. ${ }^{25}$ On the other hand, this number is similar to that reported by Cassis et al. (2007) with a sample of elderly Brazilians with dementia (3.16 \pm 1.8 comorbidities) and near to the results of MartínGarcía et al. (2013) from a sample of institutionalized elderly Spanish individuals $(96.8 \%$ had two or more chronic health conditions and $31.5 \%$ had four or more). ${ }^{39,40}$ Cassis et al. (2007) also showed that the average amount of medication prescribed per patient was $3.2 \pm 2.3$, a figure close to that obtained in the present study. ${ }^{39}$

The significant use of acetylcholinesterase inhibitor in the population under study should be highlighted, noting that such medication should be avoided at this stage of the disease, which may demonstrate some level of lack of preparation among health professionals caring for these patients. ${ }^{41}$ As the psychological and behavioral changes associated with dementia become more frequent as the disease progresses, the need for psychotropic drugs to control these symptoms is common, justifying the rates found in use of antidepressants and antipsychotics. ${ }^{41} \mathrm{On}$ the other hand, a tendency towards underdiagnosed pain and lower use of analgesic medications in elderly individuals in advanced stage of dementia was observed. ${ }^{42}$

CC measurement is often used to assess the presence of sarcopenia. ${ }^{15}$ Bonnefoy et al. (2002) demonstrated that the CC can be used as a marker of nutritional status in frail elderly patients and those with restricted mobility, with a significant correlation with body mass index (BMI) and serum albumin level $(\mathrm{r}=0.706, \mathrm{p}<0.0001) .{ }^{16}$ We noted that only $13.4 \%$ of the sample had normal CC values, indicating a high rate of malnutrition.

A high prevalence of undernourishment determined by the CC was verified in German institutionalized patients with advanced dementia, with the rate of malnourished patients in the oral feeding group estimated at $50.2 \%$, and $76.9 \%$ in the alternative feeding route group $(\mathrm{p}<0.01) .{ }^{43}$ Martins et al. (2012) noted a malnutrition rate of $53.4 \%$ in Brazilian patients with neurological disease on an enteral diet. ${ }^{44}$

In relation to pressure ulcers, the prevalence we observed was higher than that detected by Peck (1990) and Mitchell (1997), who have shown rates between 13 and 29.6\%, but similar to those described by Meier (2001) and Jaul (2006), who reported a prevalence between 49 and $64 \% .^{24,26-28}$ 
A greater burden on the caregiver was noted in the oral group compared to the alternative feeding group, but there was no statistical difference between the groups. The clinical impression is that the burden on caregivers is high. However, in the light of the available knowledge it is not possible to state what could be considered a high burden based on the Brazilian Portuguese version of the Zarit scale, although it is possible to use the scale for comparison. ${ }^{14}$

A similar result to ours was reported by Cassis et al. (2007), who assessed 67 elderly individuals with dementia, whose caregivers were mostly female and with formal education for 9.2 years. The average value on the Zarit scale was 32 points. ${ }^{39}$ Babarro et al. (2004) demonstrated a high level of burden among the caregivers of elderly individuals with dementia in Spain, with a similar sociodemographic profile to that observed in our study, with a burden on $72.3 \%$ of the sample (55.5\% at a high level). ${ }^{34}$

It should be emphasized that a high level of burden on the caregiver increases the risk of depression and raises the self-reported impression of poor quality of life. ${ }^{45}$ Therefore, high caregiver burden may indirectly affect the necessary care for patients with advanced dementia, such as feeding, change of position, and personal hygiene, as well as the financial support for such elderly people. Part of the results found in relation to pressure ulcers and nutritional status may be related to caregiver burden. Hiring a caregiver did not reduce the burden on the caregiver, nor did it have an influence on the prevalence of pressure ulcers and nutritional status.

This study has limitations, mainly related to memory bias of primary caregivers, who may underestimate the results. In addition, the sample size calculation was aimed at the composition of a cohort to evaluate the survival outcome, so it is not possible to say that the study's sample is representative for a socioeconomic analysis.

However, this study represents the first analysis of the socioeconomic profile and morbidities of patients with very advanced dementia in the Brazilian public health system. The results indicate the need for a policy aimed at caring for these patients, who present a high degree of vulnerability, a high cost of care, and, possibly, a reduction in family income, given the high rate of unemployment among primary caregivers.

\section{Resumo}

Demência avançada em uma amostra de idosos brasileiros: análise sociodemográfica e morbidades

Objetivo: investigar o perfil sociodemográfico e de morbidade de pacientes com demência avançada e dados sociodemográficos de seus respectivos cuidadores primários.

Método: foram obtidos dados de 67 idosos recrutados para um estudo observacional, prospectivo, não randomizado e não cego de pacientes em fase avançada de demência, por meio de entrevistas realizadas com os cuidadores primários. Para as análises estatísticas, foi utilizado o Statistical Package for the Social Sciences $\left(\right.$ SPSS $\left.^{\circledR}\right)$ para Windows ${ }^{\circledR}$, na versão 19.0.

Resultados: a maioria dos pacientes com demência avançada é do sexo feminino, viúva, não institucionalizada e de baixa renda. Destacam-se as elevadas taxas de acidente vascular encefálico, sarcopenia e úlceras por pressão. A maioria dos cuidadores são do sexo feminino, casados, filhos do paciente e desempregados. Somente um terço dos pacientes apresenta cuidador contratado.

Conclusão: os pacientes com demência avançada apresentam elevado grau de morbidades, baixa renda e são dependentes de cuidados de familiares, geralmente filhas desempregadas.

Palavras-chave: doença de Alzheimer, comorbidade, fatores socioeconômicos, idoso.

\section{References}

1. Brito F. Transição demográfica e desigualdades sociais no Brasil. Rev Bras Est Pop. 2008; 25(1):5-26.

2. Nações Unidas. Madrid International Plan of Action on Ageing. 2002 [cited 2014 Jul 4]. Available from: http://undesadspd.org/Portals/0/ageing/ documents/Fulltext-E.pdf.

3. Schmidt MI, Duncan BB, Azevedo e Silva G, Menezes AM, Monteiro CA Barreto SM, et al. Chronic non-communicable diseases in Brazil: burden and current challenges. Lancet. 2011; 377(9781):1949-61.

4. Herrera Jr E, Caramelli P, Silveira ASB, Nitrini R. Epidemiologic survey of dementia in a community-dwelling Brazilian population. Alzheimer Dis Assoc Disord. 2002; 16(2):103-8

5. Instituto Brasileiro de Geografia e Estatística. Censo Demográfico 2010 Características da População e dos Domicílios. 2010 [cited 2014 Jul 4] Available from: http://biblioteca.ibge.gov.br/visualizacao/periodicos/93/ cd_2010_caracteristicas_populacao_domicilios.pdf.

6. Voisin T, Vellas B. Diagnosis and treatment of patients with severe Alzheimer's disease. Drugs Aging. 2009; 26(2):135-44.

7. Ribeiro CA, Silva DAM, Rizzo LA, Ventura MM. Frequência da síndrome de imobilidade em uma enfermaria de geriatria. Geriatria \& Gerontologia. 2011; 5(3):136-9.

8. Cintra MTG, de Rezende NA, de Moraes EN, Cunha LC, da Gama Torres HO. A comparison of survival, pneumonia, and hospitalization in patients with advanced dementia and dysphagia receiving either oral or enteral nutrition. J Nutr Health Aging. 2014; 18(10):894-9.

9. McKhann GM, Knopman DS, Chertkow H, Hyman BT, Jack Jr CR, Kawas $\mathrm{CH}$, et al. The diagnosis of dementia due to Alzheimer's disease: recommendations from the National Institute on Aging-Alzheimer's Association workgroups on diagnostic guidelines for Alzheimer's disease. Alzheimers Dement. 2011; 7(3):263-9.

10. Sclan SG, Reisberg B. Functional assessment staging (FAST) in Alzheimer's disease: reliability, validity and ordinality. Int Psychogeriatr. 1992; 4(Suppl 1):55-69.

11. Lino VT, Pereira SR, Camacho LA, Ribeiro Filho ST, Buksman S. Adaptação transcultural da Escala de Independência em Atividades da Vida Diária (Escala de Katz). Cad Saúde Pública. 2008; 24(1):103-12. 
12. Padovani AR, Moraes DP, Mangili LD, Andrade CRF. Protocolo fonoaudiológico de avaliação do risco para disfagia (PARD). Rev Soc Bras Fonoaudiol. 2007; 12(3):199-205.

13. Stone R, Cafferata GL, Sangl J. Caregivers of the frail elderly: a national profile. Gerontologist. 1987; 27(5):616-26.

14. Scazufca M. Brazilian version of the Burden Interview scale for the assessment of burden of care in carers of people with mental illnesses. Rev Bras Psiquiatr. 2002; 24(1):12-7.

15. Rolland Y, Lauwers-Cances V, Cournot M, Nourhashémi F, Reynish W, Rivière $\mathrm{D}$, et al. Sarcopenia, calf circumference, and physical function of elderly women: a cross-sectional study. J Am Geriatr Soc. 2003; 51(8):1120-24.

16. Bonnefoy M, Jauffret M, Kostka T, Jusot JF. Usefulness of calf circumference measurement in assessing the nutritional state of hospitalized elderly people. Gerontology. 2002; 48(3):162-9

17. Black J, Baharestani MM, Cuddigan J, Dorner B, Edsberg L, Langemo D, et al. National Pressure Ulcer Advisory Panel's updated pressure ulcer staging system. Adv Skin Wound Care. 2007; 20(5):269-74.

18. Gnjidic D, Hilmer SN, Blyth FM, Naganathan V, Waite L, Seibel MJ, et al. Polypharmacy cutoff and outcomes: five or more medicines were used to identify community-dwelling older men at risk of different adverse outcomes. J Clin Epidemiol. 2012; 65(9):989-95.

19. Cintra MTG, de Rezende NA, Torres HOG. Qual a via mais adequada para a alimentação de idosos com demência avançada: oral ou enteral? Geriatria \& Gerontologia. 2013; 7(4):308-17.

20. Teno JM, Gozalo P, Mitchell SL, Kuo S, Fulton AT, Mor V. Feeding tubes and the prevention or healing of pressure ulcers. Arch Intern Med. 2012; 172(9):697-701.

21. Arinzon Z, Peisakh A, Berner YN. Evaluation of the benefits of enteral nutrition in long-term care elderly patients. J Am Med Dir Assoc. 2008; 9(9):657-62.

22. Alvarez-Fernández B, García-Ordoñez MA, Martínez-Manzanares C, GómezHuelgas R. Survival of a cohort of elderly patients with advanced dementia: nasogastric tube feeding as a risk factor for mortality. Int J Geriatr Psychiatry. 2005; 20(4):363-70.

23. Murphy LM, Lipman TO. Percutaneous endoscopic gastrostomy does not prolong survival in patients with dementia. Arch Intern Med. 2003; 163(11):1351-3

24. Meier DE, Ahronheim JC, Morris J, Baskin-Lyons S, Morrison RS. High short-term mortality in hospitalized patients with advanced dementia: lack of benefit of tube feeding. Arch Intern Med. 2001; 161(4):594-9.

25. Nair S, Hertan H, Pitchumoni CS. Hypoalbuminemia is a poor predictor of survival after percutaneous endoscopic gastrostomy in elderly patients with dementia. Am J Gastroenterol. 2000; 95(1):133-6.

26. Mitchell SL, Kiely DK, Lipsitz LA. The risk factors and impact on survival of feeding tube placement in nursing home residents with severe cognitive impairment. Arch Intern Med. 1997; 157(3):327-32.

27. Peck A, Cohen CE, Mulvihill MN. Long-term enteral feeding of aged demented nursing home patients. J Am Geriatr Soc. 1990; 38(11):1195-8.

28. Jaul E, Singer P, Calderon-Margalit R. Tube feeding in the demented elderly with severe disabilities. Isr Med Assoc J. 2006; 8(12):870-4.

29. Chaimowicz F, Greco DB. Dinâmica da institucionalização de idosos em Belo Horizonte, Brasil. Rev Saúde Pública. 1999; 33(5):454-60.
30. Dedecca CS, Rosandiski EN, Barbieri CV, Jungbluth A. Salário mínimo, benefício previdenciário e as famílias de baixa renda. Rev Bras Est Pop. 2006; 23(2):317-29

31. Ferreira CR, Souza SCI. "Aposentadorias e pensões" e desigualdade da renda: uma análise para o Brasil no período 1998-2003. Rev Econ Contemp. 2008; 12(1):41-66.

32. Requena GC, Val MCE, Cristófol R, Cañete J. Demencia avanzada y cuidados paliativos: características sociodemográficas y clínicas. Med Paliat. 2012; 19(2):53-7.

33. Figueiredo D, Souza L. Percepção do estado de saúde e sobrecarga em cuidadores familiares de idosos dependentes com e sem demência. Rev Port Saúde Pública. 2008; 26(1):15-24.

34. Babarro AA, Barral AG, Ponce AD, Ruiz RC, Pastor MR. Perfil y sobrecarga de los cuidadores de pacientes con demencia incluidos en el programa ALOIS Aten Primaria. 2004; 33(2):61-8.

35. Toribio-Díaz ME, Medrano-Martínez V, Moltó-Jordá JM, Beltrán-Blasco I. Red de cuidadores informales de los pacientes con demência en la provincia de Alicante, descripción de sus características. Neurología. 2013; 28(2):95-102.

36. Pimenta FAP, Bicalho MAC, Romano-Silva MA, Moraes EN, Rezende NA Doenças crônicas, cognição, declínio funcional e índice de Charlson em idosos com demência. Rev Assoc Med Bras. 2013; 59(4):326-34.

37. Ministério da Saúde do Brasil. Saúde Brasil 2008: 20 anos de Sistema Único de Saúde (SUS) no Brasil. 2009 [cited 2014 Jul 1]. Available from: http:// bvsms.saude.gov.br/bvs/publicacoes/saude_brasil_2008.pdf.

38. Lima-Costa MF, Matos DL, Camargos VP, Macinko J. Tendências em dez anos das condições de saúde de idosos brasileiros: evidências da pesquisa nacional por amostra de domicílios $(1998,2003,2008)$. Ciênc Saúde Coletiva. 2011; 16(9):3689-96

39. Cassis SVA, Karnakis T, Moraes TA, Curiati JAE, Quadrante ACR, Magaldi RM. Correlação entre o estresse do cuidador e as características clínicas do paciente portador de demência. Rev Assoc Med Bras. 2007; 53(6):497-501.

40. Martín-García S, Rodríguez-Blázquez C, Martínez-López I, Martínez Martín P, Forjaz MJ. Comorbidity, health status, and quality of life in institutionalized older people with and without dementia. Int Psychogeriatr. 2013; 25(7):1077-84

41. Parsons C, Hughes CM, Passmore AP, Lapane KL. Withholding, discontinuing and withdrawing medications in dementia patients at the end of life: a neglected problem in the disadvantaged dying? Drugs Aging. 2010; 27(6):435-49.

42. Reynolds KS, Hanson LC, DeVellis RF, Henderson M, Steinhauser KE. Disparities in pain management between cognitively intact and cognitively impaired nursing home residents. J Pain Symptom Manage. 2008; 35(4):388-96.

43. Volkert D, Pauly L, Stehle P, Sieber CC. Prevalence of malnutrition in orally and tube-fed elderly nursing home residents in Germany and its relation to health complaints and dietary intake. Gastroenterol Res Pract. 2011; 2011:247315.

44. Martins AS, Rezende NA, Torres HOG. Sobrevida e complicações em idosos com doenças neurológicas em nutrição enteral. Rev Assoc Med Bras. 2012; 58(6):691-7.

45. Schoenmakers B, Buntinx F, Delepeleire J. Factors determining the impact of care-giving on caregivers of elderly patients with dementia. A systematic literature review. Maturitas. 2010; 66(2):191-200 